\title{
Africa's Economic Growth Convergence: The Story of the China-Africa Trade
}

\author{
Samuel Adams \\ School of Public Services and Governance \\ Ghana Institute of Management and Public Administration \\ Accra, Ghana \\ sadamss2000@yahoo.com
}

\author{
Philip Adom \\ School of Public Services and Governance \\ Ghana Institute of Management and Public Administration \\ Accra Ghana \\ adomonline@yahoo.com
}

\author{
Isaac Kofi Mensah* \\ School of Economics and Management \\ Jiangxi University of Science and Technology \\ Ganzhou, China \\ 1185842364@qq.com
}

\begin{abstract}
This study explored Africa's economic growth convergence under the auspices of the China-Africa Trade relationship. The analytical framework was based on the on generalized estimating equations (GEE) and the Driscoll-Kraay (1998) estimator for 49 African countries over the period 1992 to 2017. The data analysis indicates that no evidence of unit root with cross-sectional dependence, but there was evidence of cointegration, which suggests that in the long-run the China-Africa trade relations in conjunction with population characteristics and investment in education and technology can be treated as the long-run forcing variables explaining economic growth in Africa. In addition, there is strong evidence of conditional growth convergence driven by factors such as the China-Africa trade relations, investment in education and technological innovation. The significance of the China-Trade relations on Africa's potential to converge to higher-income state suggest the need to improve upon the trade policy arrangements between China and Africa.
\end{abstract}

\section{Keywords-Economic growth; China; Africa; Trade}

\section{INTRODUCTION}

In the last four decades, China's economic rise is recognizable around the world. With a domestic market of 1.3 billion people and rising income and demand for goods and services, China has not only become a major market but also a global driver of growth. While China's demand for key inputs in the production channel, be it raw materials or intermediate goods, generate opportunities for other countries in Asia and elsewhere, its low labor costs and economies of scale have made China a fierce competitor in global markets. As such, spillover effects of China's growth in other countries could be either positive or negative depending on the production structure and comparative advantage [1]. The World Economic Outlook [2], for example, notes that the global slowdown after strong growth in 2017 and early 2018 (3.6\%) and its slowdown in $2019(3.3 \%)$ are associated with events in China among others. China's growth declined following a combination of needed regulatory tightening to rein in shadow banking and an increase in trade tensions with the United States. The report notes that the projected pickup in the second half of 2019 is predicated on an ongoing buildup of policy stimulus in China and improved relationship between the USA and China. Also, As a result, China's growth declined from 6.8 percent in the first half of 2018 to 6.0 percent in the second half of the year. The resulting weakening in import demand appeared to have an impact on trading partner exports in Asia and Europe. This data is supported by the OECD's [3] report which suggests that trade tensions, particularly between the US and China, are taking a toll on global growth, which is projected to slow down to only $3.2 \%$ this year before edging up to $3.4 \%$ in 2020 , well below the growth rates seen over the past three decades, or even in 2017-18. The report notes that renewed tensions between the United States and China could shave off more than $0.6 \%$ from global GDP over two to three years. More specifically, China remains a source of concern, as the deployment of monetary, fiscal and quasi-fiscal tools not only has uncertain effects on the activity but might continue to fuel non-financial corporate debt, already at a record high level. The Trade and Development Report [4] and the World Bank's Global Economic Prospects [5] show that slowdown in the Chinese economy and trade tension between China and the USA are among the key factors contributing to the slowdown in global growth. Global growth in 2019 has been downgraded to 2.6 percent, 0.3 percentage point below previous forecasts, reflecting weaker-than-expected international trade and investment at the start of the year.

China's search for natural resources to satisfy the demands of industrialization has led it to Sub-Saharan Africa. Indeed, the signs of China's role in the world economy are particularly manifest in Sub-Saharan Africa. Over the last decade, China has built a network of trade, aid, and investment links with over 50 African countries, and there has been a rush to buy up concessions to Africa's natural resources [6]. China became Africa's largest trading partner in 2009 and Africa's largest 
bilateral source of loans and an important provider of the Organization for Economic Co-operation and Development [7]-[8]. Gill \& Karakulah [9], for example, have noted that Chinese finance appears to have helped develop on the subcontinent and has not - by itself — jeopardized its public finances. Oqubay \& Lin [10] have also stated that whatever the argument of the China effect, they argue that the relationship has been more of a blessing than a curse. The relationship is expected to deepen even the more with initiatives like the Belt and Road Initiative, Forum on China-Africa Cooperation (FOCAC) and the recently held China International Import Expo (CIIE), which aims at opening the Chinese market to imports from Africa.

According to figures from the Ministry of Commerce of China, China remains Africa's largest trading partner with trade volumes increasing 14.1 percent year on year to $\$ 170$ billion in 2017. Trade between China and Africa in 2006 totaled more than $\$ 50$ billion, with Chinese companies importing oil from Angola and Sudan, timber from Central Africa, and copper from Zambia [6]. Since 2000, the volume of Sino-African trade has tremendously increased from US\$9.7 billion in 2000 to a peak of US\$215.9 billion in 2014 [11]. Most of the Chinese imports from African countries relate to natural resources with fuels, minerals and metals making up respectively $38.5,14.8$ and $10.7 \%$ of Chinese imports from Africa in 2016 (World Integrated Trade Solution database). Exports from China to Africa reached a peak of US\$155 billion in 2015 from a figure of US\$ 7 billion in 2002 though this fell a bit to US\$ 104 billion in 2018, while imports reached US\$ 99 billion in 2018. Similarly, Chinese FDI increased from US $\$ 0.5$ billion in 2003 to US\$43 billion in 2017, while loans increased from just 0.13 billion in 2000 to 10 billion in 2011 and reached 30 billion in 2016 with over 1592 ODA projects [12].

However, many analysts are questioning the dominance of the Chinese in the African economy. Especially, there is the argument that dominance could lead to excessive exploitation of African natural resources without the opportunity for diversification of their economies. Moreover, the tendency of Chinese companies to import labor from China, coupled with allegations of poor labor practices and unfair competition against local enterprises, has generated an anti-Chinese backlash in several African countries, notably South Africa and Zambia [6]. Haroz [13] has questioned whether Africa's future should be linked to partners like China or has become a victim of Chinese colonization [14]-[15]. These arguments are consistent with Busse et al.'s [15] assertion that Chinese activities in the region could have both positive and negative effects. Summing up, there are opportunities and risks that arise from China's various activities in Africa. Obviously, what is needed is not opinions but facts that could provide evidence-informed policy. The objective of this study, therefore, is to provide empirical evidence of the China-SSA relationship in terms of the large amounts of trade between the two partners. Our study builds on prior studies to examine the effects of trade on the economy of SSA countries. This is important because trade and investment is not a binary choice for businesses (i.e., firms don't choose between trading and investing, but often do both) and that strategies vary greatly across and within industries, SEE OECD Trade and investment report, 2019. It is important to note that a few studies have looked at the individual effects of these variables on economic growth, while a few others like Busse et al. [15] investigated their combined effect. Our study builds on the Busse et al. [15] to account for the economic and political institutions of these countries to improve the regression estimates. This aligns with the view that the policy environment influences Africa's growth patterns [16].

In achieving our research objective, we contribute to the extant literature in three main ways. First, we did not consider the effect of Chinese dominance in the SSA region, but we also account for the political and economic institutions in these countries. Second, our methodology, based on generalized estimating equations (GEE) and the Driscoll-Kraay [17] estimator control for cross-sectional dependence which has plagued many of the panel studies. Finally, we also examine the presence of nonlinearities and consequently identify threshold effects, if any. Obviously, SSA being the poorest region in the world, and economic growth regarded as the surest way to reduce poverty, the Chinese role in promoting economic growth in the region becomes an interesting topic [18]. The results of this study should help government authorities in Africa to better select or diversify their economic partners [19].

\section{LITERATURE REVIEW}

Generally, the impact of FDI and trade openness on economic growth can be positive and significant due mainly to the accumulation of physical capital (augmentation effect) and technological transfer (efficiency effect). For many developing countries and particularly in Africa, the influx of FDI and trade help to reduce the binding constraints of low domestic savings. Thus, FDI augments low domestic savings to stimulate domestic investment and the total investment and consequently FDI is expected to have a positive effect on economic growth [20][21]. For example, trade helps in upgrading skills through the importation and adoption of superior production technology and innovation and therefore exerts a positive effect on economic growth [22]. The efficiency effect is achieved through externalities and spillovers associated with the transfer of technology, marketing, and managerial skills, which have effect on productivity and subsequent economic growth [23]. Also, the global mobility of capital may limit the ability of governments to pursue bad policies [24]. These arguments are consistent with the neoliberal, modernization, and neoclassical growth paradigms, which indicate that integration into the world economy through trade and FDI should lead to improved economic performance and therefore overall economic growth within and across nations [25][26][27]. Sharma et al. [28] also argue that the integration of the world economy through trade and FDI allows for the diffusion of technology, investment, and mobility of the workforce, which facilitates the creation and sharing of ideas and opportunities for entrepreneurs. Indeed, many authors note that trade and FDI are two very important drivers of economic growth[21][22]. In support of this view, Tariq et al. [29] have argued that in 
the recent era, no country can achieve sustainable growth without integration into the world economy through trade and FDI.

Other studies, however, suggest that FDI and trade do not have an independent effect on economic growth and that initial country conditions matter, particularly the institutional infrastructure, developed financial systems and the absorptive capacity [20][23][30]. The dependency and World-Systems theorists argue that dependence on foreign investment is expected to have a negative effect on economic growth and the distribution of income as this leads to enclave economies in which multinationals dominate the economy [31][32]. The effect is more severe if it leads to the monopolization of local industries as it has a tendency to result in economic stagnation, unemployment and increasing inequality [33]. The simple reason being that multinationals are in business primarily to make profit and not to promote development and their dominance in the economy is likely to slow growth [34].

In light of the contrasting theoretical predictions, many empirical studies have been conducted to support the claims. For example, Donou-Adonsu \& Lim [35] investigate the effect of Chinese FDI on 36 African countries over the period 2003 - 2012 and find that FDI has a positive effect on the standard of living in Africa. The results based on fixed effects and instrumental variable techniques also show that Chinese investment crowds out U.S. investment in Africa, thereby undermining the preexisting relationship between Africa and the US. Explaining the findings of the results through the South-South partnership, the authors concluded that China's increasing trade with Africa is helpful to African economic development. Similarly, Mullings \& Mahabir [16] did a comparative analysis of the growth effect of China, USA, and the EU on African countries during the period 1990-2009, and report that trade; FDI and aid from China have a positive effect, while those from the USA and the EU have insignificant and growth reducing effect respectively.

Meyersson et al. [36] find that while African resource exports to the world have no effect on African growth, Africa natural resources to China has enormous effects on economic growth and investment in Africa. Similarly, Liu \& Tang [37] demonstrate that China's aid shows a positive effect on its total volume of trade and imports from Africa, while the aid from the US exhibits little impact on the US-Africa total trade and its imports from Africa. Baliamoune-Lutz [38] also finds that African countries exporting primary products to China benefit more in terms of growth and that imports from China have a positive effect on African growth.

Habyarimana \& Opoku [39] investigate the technological progress, worker efficiency, and growth dynamic relationship for Africa, and find that Sino-Africa economic relations positively impact on capital per worker efficiency in Africa. Additionally, the authors demonstrate that Sino-Africa economic relations negatively impact on technology progress in Africa. Worker efficiency substitutes technology slowdown to stimulate growth in Africa. These results predict that
China's engagement will contribute to economic growth in African countries through increasing capital per worker efficiency but cause stagnation in their technological progress.

In a related study of the effect of aid and trade on China's ODI for 50 African countries for the period 2002 2013, Dong \& Fan [40] show that exports of natural resources significantly increase China's ODI. It was reported, however, that the relationship varies according to different types of aid. Aid invested in social and economic infrastructure raises ODI, and the marginal effect diminishes as aid increases. Bandara [1] investigate the influence of international trade and investment by China in 44 Sub-Saharan African economies and reports that exports to China from Sub-Saharan African countries have a growing impact on their economic growth. More importantly, the impact of exports to the rest of the world has become less influential than before. In particular, in Sub-Saharan African countries that received foreign direct investments from China, exports to China have a significant impact on growth. In a case study of Ghana, Tang \& Gyasi [41] about $91 \%$ of the total employment projection generations between 2006 and 2010 came from Chinese investments with Ghanaians enjoying a chunk of it against the expatriates. From 2006 to 2010, about $80 \%$ or more of investments from China have been mostly concentrated in the Manufacturing, Building \& Construction and General Trade sectors of Ghana.

Contrary to the studies that show positive effects of Chinese Trade and FDI, Busse, Erdogan, \& Mühlen, [42] find that neither total net FDI inflows nor inflows from China alone have a significant impact on African growth. Likewise, Busse et al. [15] demonstrate that Chinese foreign investment and aid in Africa do not have an impact on growth. The study based on panel data over a 21 -year period (1991-2011) shows that African economies that export natural resources have benefited from positive terms-of-trade effects. In addition, there is evidence for displacement effects of African firms due to competition from China. Guillon \& Mathonnat (2019) examine ODA projects in Africa based on regression analyses and find a negative correlation between the GDP per capita and the number of Chinese ODA projects in the three broad sectors as well as the number of social ODA projects. Doku et al. [43] in a study of 20 African countries for the period 2003 -2012 based on panel least square estimation technique report that a $1 \%$ increase in China's FDI stock in Africa significantly increases Africa's GDP growth by $0.607 \%$. Koomson-Abekah \& Nwaba [44] using the ARDL technique demonstrate that Chinese FDI has a negative declining impact on economic growth in both the short and long run, while FDI from the US has an insignificant effect. The authors explain that China's FDI's inflows to Africa are allocated to capital-intensive activities which have less labor employability.

At the micro level, Elu \& Price [45] examine the case of manufacturing firms from five SSA countries for the period 1992 and 2004 and show that there is no relationship between productivity-enhancing foreign direct investment and trade with China. Additionally, increasing trade openness with 
China has no effect on the growth rate of total factor productivity. McCormick [46] analyses the impact of aid from China compared to India and demonstrates that the effects of Chinese and Indian aid seem significant for African development but do depend to a large extent on the institutional and structural conditions in the recipient country.

Also, Maswana [47] shows that the findings seemingly downplay the importance of the export-led growth hypothesis while suggesting that Africa might benefit from China's growth through technology-embodied capital good imports. In this sense, the findings support recent views that the gains from global trade depend less on the mere effects of trading than on the ability of countries to appropriately position them along the global value chain. In a later study of ten African countries highly related to China in terms of their trade intensity, Maswana [48] reported that these countries are locked in a dependence on China, which could be described as Chinese zones of influence providing some support for the claim of Chinese colonialism in modern Africa or Chinese territory" as described by Durden [49]. Maswana (2015) notes that at least one of the impacts of Africa's interactions with China is a shift away from its Euro-colonial trade pattern and into new forms of trade dependency. Lamido Sanusi, the governor of Nigeria's central bank, who points out that the Chinese practice of importing Africa's unprocessed primary commodities and exporting manufactured products to Africa is the "essence of colonialism" [50].

\section{METHOD AND DATA}

\section{A. Empirical specification}

The world over, the sustainable improvement of economic growth is crucial for the development and the welfare of the people. Central to the discourse on economic growth are two critical questions: (1) is the distribution of income shrinking or widening? and (2) are countries that are relatively poor today the same some hundred years ago? These two questions suggest different convergence criteria in the growth process. The first one suggests alpha-convergence, which concerns itself with whether the distribution of income is becoming equal or unequal. The second question suggests betaconvergence, which reflects whether poorer countries grow faster than the wealthy ones or not. While these two convergence criteria are different conceptually, they are related [51]. The beta-convergence is the necessary condition for the alpha-convergence. In other words, without beta-convergence, there cannot be alpha-convergence. Suppose we assume that beta-convergence for the economies in Africa, then in discrete time, the real per capita income can be expressed as Equation (1), where $0<\beta<1$ and $\varepsilon_{-} t$ is the stochastic disturbance term assumed to be white noise. Further rearrangement of Equation (1) produces Equation (2).

$$
\log \left(G D P p_{i t}\right)=\alpha-(1-\beta) * \log \left(G D P p_{i, t-1}\right)+\varepsilon_{i t}
$$

$$
\log \left(\frac{G D P p_{i t}}{G D P p_{i, t-1}}\right)=\alpha-\beta \log \left(G D P p_{i, t-1}\right)+\varepsilon_{i t}
$$

The restriction $0<\beta<1 \quad$ suggests betaconvergence. Thus, poorer economies in Africa grow at a faster rate than the richer ones. However, the expression contained in Equation (2) assumes absolute convergence. This means that regardless of the initial conditions in these economies, all countries converge to similar steady-state equilibrium in the long run. This is a very restrictive assumption given that the initial conditions or characteristics of economies may differ. In that case, conditional convergence becomes the highest standard. Conditional convergence assumes a unique, globally, stable, steady-state equilibrium for all economies [52]. Therefore, only countries with identical fundamentals will converge to one another. This implies that, with conditional convergence, there are likely to be multiple steady-state equilibria.

From the earlier theories of Adam Smith's absolute advantage and David Ricardo's comparative advantage to the more modernized view of Eli Heckscher and Bertil Ohlin, there seems to be a consensus on the gains from free trade. These theories reveal that countries that engage in free trade speed up their convergence rate to high income per capita. In other words, the real incomes of economies that engage in free trade are likely to be higher or grow faster than those that engage operate restricted trade policies. The post-twentieth-century trade theories such as Stolper-Samuelson theorem and Rybczinski theorem both support the view that international trade affects the distribution of the factors of production and hence the wealth of those economies involved. The major criticism of the Heskscher-Ohlin trade theory is the restrictive assumption of perfect competitive industries. However, Krugman [53] and Helpman [54] have both revealed the growth benefits of international trade even under imperfect competitive industries with increasing returns to scale.

Nonetheless, there are still a number of oppositions to the growth potential of free trade. In survey report, Scheve and Slaughter [55] showed that most people revealed consistent doubt about the growth benefits of free trade. The empirical literature remains controversial as well since there are pieces of evidence to support [56] and oppose [57][58] the growth benefits of free trade. Based on the above, we controlled for trade effects (specifically focusing on China-Africa trade relationships - china exports to and import from Africa ) and other important factors such as population density, human capital (a measure of education) and capital investment. The empirical model is expressed as Equation (3). 


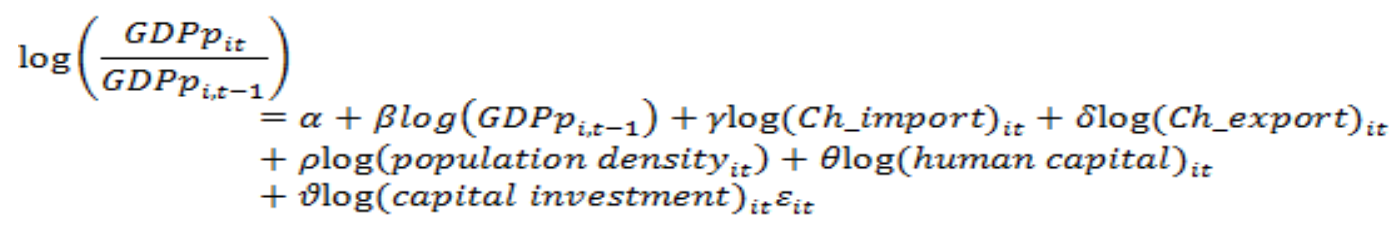

\section{B. Econometric strategy}

The econometric approach proceeded as follows. Equation 2 was estimated using the population-averaged estimator (based on generalized estimating equations (GEE) and the Driscoll-Kraay (1998) estimator. These methods deal with potential problems of serial correlation, heteroscedasticity, and cross-sectional dependence. In estimating Equation 2, we proceeded from the specific to general; this was done to ascertain the stable nature of the results. First, we estimated Equation 2, without the controlled variables. Then we included the effects of trade, human capital, capital investment, and population density successively. The population-averaged and Driscoll-Kraay estimators require stationary series. This means that, in the presence of unit root, differencing the series to achieve stationarity may cause loss of information, hence affect the degrees of freedom, and bias the estimates. Therefore, as a further robustness check, we tested for cointegration using the approaches of Pedroni [59][60] and Westerlun [61], and the Mean-Group (MG) estimator by Pesaran \& Smith [62] to obtain the long-run cointegrating parameters. The MG estimator allows for heterogeneity in slope coefficients among groups and then averages these estimates to obtain the longrun coefficients. However, the approach by Pesaran and Smith (1995) does not model cross-sectional dependence. The augmented Mean Group (AMG) estimator by Eberhardt [63], which accounts for heterogeneity in slope coefficients and cross-sectional dependence, was also applied to the final model. The AMG is similar to the approach by Pesaran [64]. However, unlike Pesaran (2006) that treats the unobservable common factors as nuisance, in a cross-section production function, the unobservable represent total factor productivity in $\mathrm{AMG}$.

\section{Data type and source}

This study used annual panel data spanning from 1992 to 2017 that consists of 49 African countries. Income is measured as the real gross domestic product per capita. Economic growth is the growth rate in real gross domestic product per capita. Human capital is measured using the human capital index, which captures years of schooling and returns to education. Population density, which captures population growth, is defined in this study as the total population per square kilometer of land area. China export to and import from Africa are measured in millions US dollars. Capital investment scaled as percent of GDP is defined as the gross capital formation (formerly domestic investment). It consists of the outlays on additions to the fixed assets of the economy plus net changes in the level of inventories. Data on China's import from and export to Africa come from the UNComtrade. Data on human capital index come from the Penn World Data. The rest of the variables come from the World Bank development indicator database. As a preliminary analysis, Table I shows the descriptive statistics of all the variables. All variables contained in Table I and subsequent ones are in log form. Table II shows the test for unit root with cross-sectional dependence based on the Pesaran [65] approach. The results contained in the table reveal that none of the variables exhibit unit root with cross-sectional dependence. This suggests that we apply the first generation unit root technique. In this paper, we applied Im-Pesaran-Shin test. We found that except for population density, human capital index and China's export to Africa, which showed unit root in levels, the rest of the variables are stationary in levels. In the non-cointegration models (Driscoll and Kray and Population average based on GEE), we differenced the nonstationary series ones to obtain stationarity.

Table I : Summary Statistics

\begin{tabular}{|c|c|c|c|c|c|}
\hline Variable & Mean & Std & Min & Max & obs \\
\hline $\begin{array}{c}\text { Gdp growth per } \\
\text { capital }\end{array}$ & .0173 & .0730 & -.9735 & .8776 & 1,204 \\
\hline Capital investment $\mathrm{t}_{\mathrm{t}}$ & 2.9789 & .4930 & -1.2379 & 4.3011 & 1,140 \\
\hline population density $_{\mathrm{t}}$ & 3.6876 & 1.2961 & .6090 & 6.4345 & 1,267 \\
\hline human capital \\
Ch_exp to Africa $_{\mathrm{t}}$ & -.7675 & .2702 & -1.6145 & -.2269 & 1,150 \\
\hline Ch_imp from Africa $_{\mathrm{t}}$ & 2.4393 & 2.4086 & -2.1229 & 10.7755 & 1,211 \\
\hline Cotal trade & 2.7878 & 3.6605 & -13.8155 & 10.4212 & 1,211 \\
\hline to $_{\mathrm{t}}$ & 4.9136 & 2.4680 & -2.1229 & 10.7945 & 1,211 \\
\hline
\end{tabular}

Table II : Pesaran (2015) test for unit root with weak crosssectional dependence

Ho: variables have a unit root with weak cross-sectional dependent

\begin{tabular}{|c|c|c|c|}
\hline Variable & CD & P-value & Decision \\
\hline $\begin{array}{c}\text { gdp growth per } \\
\text { capita }\end{array}$ & 13.367 & .000 & Reject \\
\hline capital investment $_{\mathbf{t}}$ & 15.521 & .000 & Reject \\
\hline population density $_{\mathbf{t}}$ & 153.613 & .000 & Reject \\
\hline human capital $_{\mathbf{t}}$ & 45.765 & .000 & Reject \\
\hline Ch_expto Africa $_{\mathbf{t}}$ & 151.680 & .000 & Reject \\
\hline $\begin{array}{c}\text { Ch_imp from } \\
\text { Africa }\end{array}$ & 86.456 & .000 & Reject \\
\hline total trade \\
\end{tabular}

\section{RESULTS AND DISCUSSION}

This section shows the main results of the study based on the Driscoll and Kraay method and Population Average estimator based on the generalized estimating equation (GEE). Table III shows the result. The first part of the table contains 
the result based on the population average estimator using the GEE approach, while the second part of the table shows the result based on the Driscoll and Kraay approach. In the first part of the table, the model I show that the effect of the initial level of income on the growth in per capita real income is negative but insignificant. This clearly denotes the absence of absolute convergence. However, when we controlled for the effects of China-Africa trade relations, the effect of the initial real income per capita on the growth rate of per capita real income becomes significantly negative. This implies that trade relations between China and Africa enhance the growth rate of poor economies than the wealthier ones. In other words, the convergence to higher real income per capita is crucially dependent on the trade relations between Africa and China. As shown from model I to II, the coefficient of the initial real income per capita has improved in absolute terms from 0.0057 to 0.0119 . The evidence of conditional convergence remains intact even when we control for other variables such as human capital, population density, and domestic capital investment. However, the speed of adjustment falls slowly. The evidence of conditional convergence in real per capita growth confirms the findings of Zahonogo[66]. In this study, this also focused on Africa's economic growth and global trade, the coefficient of the initial real income per capita in absolute terms range from 0.0334 to 0.0968 .

On its own, China's exports to Africa and imports from Africa, which is Africa's export to China, exert significant positive effect on Africa's real income per capita growth. This implies that trade relations with China promote economic growth in Africa. The growth-enhancing effect of China-Africa trade could stem from the higher demand for oil by China and the low cost of China's export. Albeit, the latter transmission channel seems to cause displacement in the Africa markets[67]. Zhonogo [66], Baliamoune-Lutz [38] and Zafar [6] have all revealed evidence in support of the growth benefits of Africa's trade relations with China.

Capital investment and human capital exert a significant positive effect on economic growth in Africa. This confirms the findings of Zhonogo[66] confirm the positive effect of capital investment while Ogundari \& Awokuse [68] confirm the positive effects of human capital. Abdelbary \& Benhin [69] confirm both the positive effects of human capital and capital investment. In contrast, higher population density exerts significant negative effects on economic growth. Higher population density could suggest higher dependency on the working few. Zhonogo [66] also found the effect of population growth on economic growth to be negative.

The second part of Table III shows the results based on Driscoll and Kraay method to correct for cross-sectional dependence. The findings are very robust. The effect of the initial income per capita on economic growth is consistently negative and statistically significant. More important is the result that convergence towards higher income per capita increases with the introduction of trade. This implies that China-Africa trade has had a significant impact on the convergence rate in Africa. The effects of human capital and domestic capital investment are significantly positive, which confirms the theoretical positions of the Solow and Harod-
Domar models. In contrast, the effect of population density is negative but statistically not significant.

In Table IV, we used total trade, which is the sum of imports and exports to capture the trade relations between China and Africa, and the results remain very consistent irrespective of the estimator used. There is evidence of conditional growth convergence, driven upward by the ChinaAfrica trade relations. However, the evidence regarding population effects become weaker. 
Table III: Estimation results_Export \& Import

Dependent variable: GDP growth per capita

\begin{tabular}{|c|c|c|c|c|c|c|c|c|c|c|}
\hline & \multicolumn{5}{|c|}{ Population-averaged Model based on GEE } & \multicolumn{5}{|c|}{ Driscoll \& Kraay model } \\
\hline VARIABLES & I & II & III & IV & $\mathrm{V}$ & V I & VII & VIII & IX & $\mathrm{X}$ \\
\hline \multirow{2}{*}{ Initial gdppc } & -0.00567 & $-0.0119 * *$ & $-0.00668^{* *}$ & $-0.00802 * * *$ & -0.00448 & $-0.0733 * * *$ & $-0.111 * * *$ & $-0.0759 * * *$ & $-0.0760 * * *$ & $-0.0613 * * *$ \\
\hline & $(0.00367)$ & $(0.00590)$ & $(0.00273)$ & $(0.00273)$ & $(0.00273)$ & $(0.0248)$ & $(0.0314)$ & $(0.0127)$ & $(0.0121)$ & $(0.0153)$ \\
\hline \multirow[t]{2}{*}{ Capital investment } & & & $0.0275^{* * *}$ & $0.0283^{* * * *}$ & $0.0267 * * *$ & & & $0.0294 * * *$ & $0.0294 * * *$ & $0.0318 * * *$ \\
\hline & & & $(0.00619)$ & $(0.00624)$ & $(0.00509)$ & & & $(0.00460)$ & $(0.00415)$ & $(0.00460)$ \\
\hline \multirow[t]{2}{*}{ Population density } & & & & -0.394 & $-0.687 * * *$ & & & & -0.0576 & -0.363 \\
\hline & & & & $(0.254)$ & $(0.214)$ & & & & $(0.497)$ & $(0.469)$ \\
\hline \multirow[t]{2}{*}{ Human capital } & & & & & $0.931 * * *$ & & & & & $0.733 * * *$ \\
\hline & & & & & $(0.242)$ & & & & & $(0.235)$ \\
\hline \multirow[t]{2}{*}{ Ch_exp to Africa } & & $0.0219 * *$ & $0.0151 * * *$ & $0.0153 * * *$ & $0.0122 * * *$ & & $0.0171 *$ & $0.0128 * * *$ & $0.0128 * * *$ & $0.0106^{* * *}$ \\
\hline & & $(0.0104)$ & $(0.00429)$ & $(0.00432)$ & $(0.00412)$ & & $(0.00964)$ & $(0.00398)$ & $(0.00390)$ & $(0.00426)$ \\
\hline \multirow[t]{2}{*}{ Ch_imp from Africa } & & 0.00216 **** & $0.000827 *$ & $0.000960 * *$ & 0.000543 & & $0.00722^{*} * * *$ & 0.00337 *** & $0.00338^{* * * *}$ & $0.00219 * *$ \\
\hline & & $(0.000714)$ & $(0.000477)$ & $(0.000478)$ & $(0.000411)$ & & $(0.00190)$ & $(0.00114)$ & $(0.00111)$ & $(0.000927)$ \\
\hline \multirow[t]{2}{*}{ Constant } & $0.0572 * *$ & $0.0919 * *$ & -0.0251 & -0.00885 & -0.0318 & $0.534 * * *$ & $0.774 * * *$ & $0.450 * * *$ & $0.452 * * *$ & $0.343 * * *$ \\
\hline & $(0.0278)$ & $(0.0422)$ & $(0.0215)$ & $(0.0261)$ & $(0.0250)$ & $(0.178)$ & $(0.219)$ & $(0.0881)$ & $(0.0850)$ & $(0.115)$ \\
\hline Observations & 1,204 & 1,070 & 979 & 978 & 918 & 1,204 & 1,070 & 979 & 978 & 918 \\
\hline Number of ID & 49 & 49 & 48 & 48 & 48 & 49 & 49 & 48 & 48 & 48 \\
\hline
\end{tabular}

Standard errors in parentheses; $* * * p<0.01, * * p<0.05, * p<0.1$

Table IV: Estimation results _ total trade

Dependent variable: GDP growth per capita

\begin{tabular}{|c|c|c|c|c|c|c|c|c|}
\hline \multirow[b]{2}{*}{ VARIABLES } & \multicolumn{5}{|c|}{ Population-averaged Model based on GEE } & \multicolumn{3}{|c|}{ Driscoll \& Kraay model } \\
\hline & $\mathrm{I}$ & II & III & IV & $\mathrm{V}$ & VI & VII & VIII \\
\hline \multirow[t]{2}{*}{ Initial gdppc } & -0.00382 & $-0.00411 *$ & -0.00298 & $-7.47 \mathrm{e}-05$ & $-0.0702 * * *$ & $-0.0507 * * *$ & $-0.0479 * * *$ & $-0.0328^{*}$ \\
\hline & $(0.00319)$ & $(0.00242)$ & $(0.00298)$ & $(0.00260)$ & $(0.0253)$ & $(0.0133)$ & $(0.0145)$ & $(0.0185)$ \\
\hline \multirow[t]{2}{*}{ Capital investment } & & $0.0285^{* * *}$ & $0.0274 * * *$ & $0.0234 * * *$ & & $0.0337 * * *$ & $0.0312 * * *$ & $0.0294 * * *$ \\
\hline & & $(0.00534)$ & $(0.00529)$ & $(0.00447)$ & & $(0.00538)$ & $(0.00462)$ & $(0.00491)$ \\
\hline \multirow[t]{2}{*}{ Population density } & & & 0.367 & -0.00750 & & & 1.113 & 0.739 \\
\hline & & & $(0.452)$ & $(0.385)$ & & & $(0.728)$ & $(0.661)$ \\
\hline \multirow[t]{2}{*}{ Human capital } & & & & $1.027 * * *$ & & & & $0.905^{* * *}$ \\
\hline & & & & $(0.192)$ & & & & $(0.292)$ \\
\hline \multirow[t]{2}{*}{ Total trade } & $0.0294 * * *$ & 0.0190 *** & 0.0189 *** & $0.0180^{* * * *}$ & $0.0242 * * *$ & $0.0176^{* * * *}$ & $0.0170^{* * *}$ & 0.0159 *** \\
\hline & $(0.00956)$ & $(0.00443)$ & $(0.00441)$ & $(0.00492)$ & $(0.00767)$ & $(0.00478)$ & $(0.00485)$ & $(0.00467)$ \\
\hline \multirow[t]{2}{*}{ Constant } & $0.0385^{*}$ & $-0.0454 * * *$ & $-0.0590 * *$ & $-0.0710 * * *$ & $0.506^{* * *}$ & 0.266 *** & $0.227 *$ & 0.125 \\
\hline & $(0.0231)$ & $(0.0166)$ & $(0.0258)$ & $(0.0232)$ & $(0.180)$ & $(0.0963)$ & $(0.114)$ & $(0.138)$ \\
\hline Observations & 1,141 & 1,037 & 1,036 & 948 & 1,141 & 1,037 & 1,036 & 948 \\
\hline Number of ID & 49 & 48 & 48 & 48 & 49 & 48 & 48 & 48 \\
\hline
\end{tabular}

\section{A. Robustness Check}

Both the population-averaged (based on GEE) and DriscollKraay estimators assume stationarity. In the presence of nonstationarity, differencing will lead to loss of some information, which could affect negatively the degrees of freedom and bias the results. Therefore, as a further robustness check, we tested for co-integration and then applied the Mean Group and Augmented Mean Group co-integrating estimators.

\section{1) Test for cointegration}

This study applied three cointegration tests namely the Kao, Pedroni and Westerlund co-integrating test. All tests have a similar null hypothesis of no co-integration. However, they differ in their alternatives. In the case of Kao and Pedroni, the alternative hypothesis is that there exists co-integration in all panels, while Westerlund test against the alternative that some of the panels are co-integrated. Table $\mathrm{V}$ is based on using import and export jointly but independently in the same model. As revealed in the table, there is enough statistical evidence to reject the claim of no co-integration and accept the claim of co-integration in the panels. Thus, the independent variables considered in this study can be treated as the long-run forcing variables explaining economic growth in Africa.

Table IV: Test for co-integration

Dependent variable: GDP growth per capita

\begin{tabular}{|c|c|c|c|c|c|}
\hline \multicolumn{2}{|c|}{ Kao cointegration test } & \multicolumn{2}{|c|}{ Pedroni cointegration test } & \multicolumn{2}{l|}{ Westerlund cointegration test } \\
\hline Test & statistics & test & statistics & Test & statistics \\
\hline Modified DF & $-20.3510^{* * *}$ & Modified PP & $-2.2097 * *$ & Variance ratio & $-5.5653^{* * *}$ \\
\hline DF & $-18.9566^{* * *}$ & $P P$ & $-17.6317^{* * *}$ & & \\
\hline Augmented DF & $-13.0429 * * *$ & Augmented DF & $-20.2309 * * *$ & & \\
\hline Unadjusted modified DF & $-26.8431^{* * *}$ & & & & \\
\hline Unadjusted DF & $-19.9975^{* * *}$ & & & & \\
\hline
\end{tabular}




\section{2) Long-run estimates}

Table V shows the result for both total trade and import and export. The model I in the first part of the table shows that the initial income per capita exerts a negative and significant effect on economic growth in Africa. This is evidence in support of absolute convergence. However, the inclusion of the trade variables (export and import) increases this coefficient (in absolute terms) significantly. As shown in the table (Model II), the coefficient has increased from 0.268 to 0.384 (in absolute terms). This clearly supports the earlier claim of conditional growth convergence in Africa driven by the China-Africa trade relations. However, in contrast to the evidence presented in Tables III and IV, China's export to Africa seems to have a significant impact on economic growth than Africa's export to China. As Table V reveals, the growth-enhancing potential of Africa's export to China is weaker. Moreover, the inclusion of human capital and capital investment, which have positive effects on economic growth, increases the effect of the initial income per capita on economic growth. This suggests the significance of human capital (education) and technological investment for Africa economies in converging to a higher income per capita state. Population density seems to exert negative but insignificant effect on economic growth. These results remain very robust when we use total trade instead of the decomposition. The inclusion of total trade increases the effect of the initial income per capita on economic growth from 0.268 (Model I) to 0.366 (Model VI) in absolute terms. Similarly, the inclusion of human capital and capital investment, which influences economic growth positively, increases the negative effect of the initial income per capita. Since the MG estimator does not model cross-sectional dependence, we applied the augmented MG estimator to deal with this problem. Table VI shows the results. Generally, there is evidence of conditional convergence driven by trade, human capital, and capital investment. These results confirm the result that convergence of Africa countries to higher per capita income is conditional on trade relations (especially with China) and investment in education and technology diffusion.

\section{Table V Mean Group Estimator}

Dependent variable: GDP growth per capita

\begin{tabular}{|c|c|c|c|c|c|c|c|c|c|}
\hline \multirow[b]{2}{*}{ VARIABLES } & \multicolumn{5}{|c|}{ Export and Import } & \multicolumn{4}{|c|}{ Total trade } \\
\hline & MGI & MGII & MGIII & MGIV & MGV & MGVI & MGVII & MGVIII & MGIX \\
\hline \multirow{2}{*}{ Initial gdppc } & $-0.268^{* * * * *}$ & $-0.384 * * *$ & $-0400^{* * * * *}$ & $-0.521^{* * * *}$ & $-0673 * * * *$ & $-0366^{* * * *}$ & 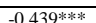 & $-0,542^{* * * * *}$ & -0649 ***** \\
\hline & $(0.0319)$ & $(0.0467)$ & $(0.0434)$ & $(0.0480)$ & $(0.0625)$ & $(0.0412)$ & $(0.0445)$ & $(0.0513)$ & $(0.0594)$ \\
\hline \multirow[t]{2}{*}{ Capital investment } & & & $0.0308^{* * * * *}$ & $0.0227^{*}$ & $0.0334^{* * * * * *}$ & & $0.0368^{* * * * *}$ & $0.0311^{* * *}$ & $0.0350^{* * * *}$ \\
\hline & & & $(0.0119)$ & $(0.0117)$ & $\begin{array}{l}(0.0113) \\
\end{array}$ & & $\begin{array}{l}(0.0120) \\
\end{array}$ & $(0.0123)$ & $(0.0109)$ \\
\hline \multirow[t]{2}{*}{ Population density } & & & & -0.352 & -0.284 & & & -0.170 & -0.0686 \\
\hline & & & & $(0.431)$ & $(0.743)$ & & & $(0.600)$ & $(0.455)$ \\
\hline \multirow{2}{*}{ Human capital } & & & & & $0.778^{* * * *}$ & & & & $0.719^{* * * * *}$ \\
\hline & & & & & $(0.168)$ & & & & $(0.157)$ \\
\hline \multirow{2}{*}{ Ch_exp to Africa } & & $0.0203 * * * *$ & $0.0156^{* * * *}$ & $0.0165^{* * * *}$ & 0.00681 & & & & \\
\hline & & $\begin{array}{l}(0.00476) \\
\end{array}$ & $\begin{array}{l}(0.00520) \\
\end{array}$ & $\begin{array}{l}(0.00575) \\
\end{array}$ & $\begin{array}{l}(0.00460) \\
\end{array}$ & & & & \\
\hline \multirow{2}{*}{ Ch_imp from Africa } & & 0.00166 & 0.00222 & 0.00171 & $0.00204 *$ & & & & \\
\hline & & $\begin{array}{l}(0.00147) \\
\end{array}$ & $\begin{array}{l}(0.00167) \\
\end{array}$ & $(0.00153)$ & $\begin{array}{l}(0.00114) \\
\end{array}$ & & & & \\
\hline \multirow[t]{2}{*}{ Total trade } & & & & & & $0.0188^{* * * *}$ & $0.0145^{* * * *}$ & $0.0118^{* * *}$ & $0.00788^{*}$ \\
\hline & & & & & & $\begin{array}{l}0.00434) \\
\end{array}$ & $\begin{array}{l}(0.00534) \\
\end{array}$ & $(0.00504)$ & $(0.00420)$ \\
\hline \multirow[t]{2}{*}{ Constant } & $1.722^{* * * * *}$ & $2.452 * * * *$ & $2.707 * * * *$ & $4.473^{* * * *}$ & $5.568^{* * * *}$ & $2.395^{* * * * *}$ & $2.796^{* * * *}$ & $3.765^{* * *}$ & $4.855^{* * * * *}$ \\
\hline & $(0.194)$ & $(0.328)$ & $(0.346)$ & $(1.199)$ & $(2.089)$ & $(0.284)$ & $(0.310)$ & $(1.534)$ & $(1.378)$ \\
\hline Observations & 1,204 & 1,077 & 978 & 963 & 904 & 1,149 & 1,043 & 1,036 & 937 \\
\hline Number of ID & 49 & 49 & 47 & 45 & 44 & 49 & 48 & 47 & 44 \\
\hline
\end{tabular}

All coefficients present represent averages across groups (ID). Coefficient averages computed as outlier-robust means.

Table V Augmented Mean Group Estimator

Dependent variable: GDP growth per capita

\begin{tabular}{|c|c|c|c|c|c|c|c|c|c|c|}
\hline & (1) & (2) & (3) & (4) & $(5)$ & (6) & (7) & (8) & (9) & $(10)$ \\
\hline VARIABLES & AMG I & AMG II & AMG III & AMG IV & AMG V & AMG VI & AMG VII & AMG VIII & AMG IX & AMG X \\
\hline \multirow[t]{2}{*}{ Initial gdppc } & $-0.346 * * *$ & $-0.401 * * *$ & $-0.492^{* * * *}$ & $-0.656^{* * * *}$ & $-0.731^{* * * *}$ & $-0.346^{* * * *}$ & $-0.407 * * *$ & $-0.532 * * *$ & $-0.625 * * *$ & $-0.749 * * * *$ \\
\hline & $(0.0387)$ & $(0.0450)$ & $(0.0508)$ & $(0.0787)$ & $(0.0703)$ & $(0.0387)$ & $(0.0434)$ & $(0.0543)$ & $(0.0599)$ & $(0.0613)$ \\
\hline \multirow[t]{2}{*}{ Capital investment } & & & $0.0592^{* * *}$ & $0.0559^{* * *}$ & $0.0467^{* * *}$ & & & $0.0703^{* *}$ & $0.0745^{* *}$ & $0.0690^{* * *}$ \\
\hline & & & $(0.0241)$ & $(0.0233)$ & $(0.0214)$ & & & $(0.0294)$ & $(0.0299)$ & $(0.0292)$ \\
\hline \multirow[t]{2}{*}{$\begin{array}{l}\text { Population density } \\
\end{array}$} & & & & -0.843 & 0.103 & & & & -0.771 & 0.346 \\
\hline & & & & $(1.406)$ & $(1.672)$ & & & & $\begin{array}{l}(0.997) \\
\end{array}$ & $(1.034)$ \\
\hline \multirow[t]{2}{*}{ Human capital } & & & & & $1.264^{* * * *}$ & & & & & $0.927^{* * * *}$ \\
\hline & & & & & $(0.265)$ & & & & & $\begin{array}{l}0.311) \\
(0.0)\end{array}$ \\
\hline \multirow[t]{2}{*}{ Ch_exp to Africa } & & $0.0246^{* * * *}$ & $0.0169^{* * * *}$ & $0.0140^{* * *}$ & 0.00887 & & & & & \\
\hline & & $(0.00734)$ & $(0.00555)$ & $(0.00650)$ & $(0.00645)$ & & & & & \\
\hline \multirow[t]{2}{*}{ Ch_imp from Africa } & & 0.00278 & 0.00273 & 0.00297 & 0.00445 & & & & & \\
\hline & & $(0.00273)$ & $(0.00264)$ & $(0.00304)$ & $(0.00323)$ & & & & & \\
\hline \multirow[t]{2}{*}{ Total trade } & & & & & & & $0.0250^{* * * *}$ & $0.0158^{* * *}$ & $0.0163^{* * *}$ & $0.0167 * *$ \\
\hline & & & & & & & $(0.00634)$ & $(0.00639)$ & $(0.00755)$ & $(0.00747)$ \\
\hline \multirow[t]{2}{*}{ CDP } & $0.813 * * *$ & $0.464 *$ & $0.706 * *$ & $1.255^{* * * *}$ & $1.242^{* * * *}$ & $0.813^{* * * *}$ & $0.672^{* * * *}$ & $0.573^{* *}$ & $0.868^{* * * * *}$ & $0.755^{* * * *}$ \\
\hline & $(0.221)$ & $(0.240)$ & $(0.282)$ & $(0.420)$ & $(0.280)$ & $(0.221)$ & $(0.209)$ & $(0.240)$ & $(0.263)$ & $(0.280)$ \\
\hline \multirow[t]{2}{*}{$=000007 \_t$} & $-0.00922^{*}$ & -0.00506 & -0.00395 & 0.00305 & -0.0175 & $-0.00922^{*}$ & -0.00637 & -0.00198 & 0.0194 & -0.0257 \\
\hline & $(0.00475)$ & $(0.00412)$ & $(0.00303)$ & $(0.0312)$ & $(0.0403)$ & $(0.00475)$ & $(0.00388)$ & $(0.00420)$ & $(0.0293)$ & $(0.0287)$ \\
\hline \multirow[t]{2}{*}{ Constant } & $2.445^{* * * *}$ & $2.940^{* * * *}$ & $3.368^{* * * * *}$ & 5.189 & 4.852 & $2.445^{* * * *}$ & $2.803^{* * * *}$ & $3.628 * * *$ & $6.189^{* * *}$ & 3.880 \\
\hline & $(0.307)$ & $(0.382)$ & $(0.408)$ & $(3.435)$ & $(6.525)$ & $(0.307)$ & $(0.327)$ & $(0.411)$ & $(2.826)$ & $(3.262)$ \\
\hline Observations & 4204 & 1071 & 964 & 963 & 886 & 2204 & 149 & 1037 & 1022 & 937 \\
\hline Number of ID & $\frac{120}{49}$ & $\frac{1,011}{48}$ & $\frac{0+4}{45}$ & $\frac{03}{45}$ & $\frac{600}{42}$ & $\frac{1,204}{49}$ & $\frac{1,149}{49}$ & $\frac{1,037}{47}$ & $\frac{1,022}{45}$ & $\frac{311}{44}$ \\
\hline
\end{tabular}

. Standard errors in parentheses. $* * * p<0.01, * * p<0.05, * p<0.1$. Common dynamic process $(C D P)$ 


\section{CONCLUSION AND POLICY RECOMMENDATION}

This study applied an econometric technique to analyze the growing convergence in Africa and the role of ChinaAfrica trade relations. The paper used annual panel timeseries data that consisted of 49 Africa countries spanning from 1992 to 2017. Preliminary analysis of the data showed no evidence of unit root with cross-sectional dependence, but there was evidence of cointegration, which suggests that in the long-run the China-Africa trade relations in conjunction with population characteristics and investment in education and technology can be treated as the long-run forcing variables explaining economic growth in Africa. The main results of the study are summarized as follows.

There is strong evidence of conditional growth convergence driven by factors such as the China-Africa trade relations, investment in education and technological innovation. The significance of the China-Trade relations on Africa's potential to converge to higher-income state suggest the need to improve upon the trade policy arrangements between China and Africa. More importantly, such a trade reform should seek to protect local establishments that may seem to be affected negatively by the intrusion of Chinese products. This may require for instance Africa governments guaranteeing markets for these vulnerable establishments. Moreover, it may be important to enhance the competitiveness of Africa's products by shifting from the export of raw products to processed ones. In this regard, special tax incentive that seeks to boost innovation within the local establishment can prove critical. Lastly, as shown in this study, other factors such as investment in education and technology affect the rate of convergence to higher income per capita. Consequently, national commitment to boost these indicators in Africa could prove very crucial in Africa's growth transformation.

\section{REFERENCES}

[1]. Bandara, A. (2012). Growth spillovers: Do China's trade and investment matter for African growth?. Tanzania: United Nations Development Program), available at http://www. undp. org/content/dam/tanzania/GrowthSpillovers. pdf.

[2]. World Economic Outlook (2019). Growth Slowdown, Precarious Recovery. IMF, United Nations, New York.

[3]. OECD Trade and Investment Report (2019). Trade, invest, or partner? Different strategies for different objectives

[4]. UNCTAD Trade and development report (2018). POWER, PLATFORMS AND THE FREE TRADE DELUSION United Nations. New York

[5]. World Bank. 2019. Global Economic Prospects, June 2019: Heightened Tensions, Subdued Investment. Washington, DC: World Bank. doi: 10.1596/978-1-4648-1398-6

[6]. Zafar, A. (2007). The growing relationship between China and Sub-Saharan Africa: Macroeconomic, trade, investment, and aid links. The World Bank Research Observer, 22(1), 103-130.

[7]. Shinn, D. H. (2019). China's Economic Impact on Africa. In Oxford Research Encyclopedia of Politics.

[8]. King, K. (2013). China's aid and soft power in Africa. The Case of Education and Training. Woodbridge: James Currey.

[9]. Gill, I. S., \& Karakulah, K. (2019). Is China Helping Africa? Growth and Public Debt Effects of the Subcontinent's Biggest Investor.

[10]. Oqubay, A., \& Lin, J. Y. (2019). Introduction to China-Africa and an Economic Transformation. China-Africa and an Economic
[11]. United Nations Comtrade Database (2018). United Nations comtrade database. URL: https://comtrade. un. org/. Access, 29, 82019.

[12]. Guillon, M., \& Mathonnat, J. (2019). What can we learn on Chinese aid allocation motivations from available data? A sectorial analysis of Chinese aid to African countries. China Economic Review.

[13]. Haroz, D. (2011). China in Africa: Symbiosis of Exploitation. Fletcher F. World Aff., 35, 65.

[14]. Ayieko, B. (2019). Launching Platform China's deliberations at the two sessions lend experience to poverty alleviation in Africa. ChinAfrica, (4), 11.

[15]. Busse, M., Erdogan, C., \& Mühlen, H. (2016). China's impact on Africa-The role of trade, FDI and aid. Kyklos, 69(2), 228-262.

[16]. Mullings, R., \& Mahabir, A. (2018). Growth by Destination: The Role of Trade in Africa's Recent Growth Episode. World Development, 102, 243-261

[17]. Driscoll, J.C., Kraay, A.C., 1998. Consistent covariance matrix estimation with spatially dependent panel data. Review of Economics and Statistics 80, 549-560.

[18]. Ademola, O. T., Bankole, A. S., \& Adewuyi, A. O. (2016) China-Africa trade relations: Insights from AERC scoping studies. In The Power of the Chinese Dragon (pp. 69-97). Palgrave Macmillan, London.

[19]. Donou-Adonsou, F., \& Lim, S. (2018). On the importance of Chinese investment in Africa. Review of development finance, 8(1), 6373.

[20]. Asamoah, L. A., Mensah, E. K., \& Bondzie, E. A. (2019). Trade openness, FDI and economic growth in sub-Saharan Africa: do institutions matter?. Transnational Corporations Review, 11(1), 65-79.

[21]. Belloumi, M. (2014). The relationship between trade, FDI and economic growth in Tunisia: An application of the autoregressive distributed lag model. Economic systems, 38(2), 269-287.

[22]. Kalai, M., \& Zghidi, N. (2019). Foreign direct investment, trade, and economic growth in MENA countries: empirical analysis using ARDL bounds testing approach. Journal of the Knowledge Economy, 10(1), 397-421.

[23]. Carkovic, M., \& Levine, R. (2005). Does foreign direct investment accelerate economic growth?. Does foreign direct investment promote development, 195.

[24]. Adams, S. (2009). Foreign direct investment, domestic investment, and economic growth in Sub-Saharan Africa. Journal of Policy Modeling, 31(6), 939-949.

[25]. Babalola, S. J., Mohd, S., Ehigiamusoe, K. U., \& Onikola, H. (2019). Impact Of Foreign Direct Investment, Aid And Trade On Economic Growth In Nigeria. The Journal of Developing Areas, 53(4).

[26]. Sun, P., \& Heshmati, A. (2010). International trade and its effects on economic growth in China.

[27]. Wade, R. H. (2001). The rising inequality of world income distribution. Finance \& Development, 38, pp. 37-36

[28]. Sharma, K., Chakrabarti, A. S., \& Chakraborti, A. (2019). Multi-layered network structure: Relationship between financial and macroeconomic dynamics New Perspectives and Challenges in Econophysics and Sociophysics (pp. 117-131): Springer.

[29]. Tariq, G., Sun, H., Haris, M., Kong, Y., \& Nadeem, A. (2018) Trade liberalization, FDI inflows economic growth and environmental sustanaibility in Pakistan and India. Journal of Agriculture and Environment for International Development (JAEID), 112(2), 253-269

[30]. Alfaro L, Areendam C, Kalemli-Ozcan S, Sayek S (2004). FDI and Economic Growth: The Role of the Financial Markets, J. Inter. Econs. 64(1): 89-112.

[31]. Bornschier V, Chase - Dunn C (1985). Transnational Corporations and Underdevelopment. New York: Praeger

[32]. Ajayi S (2006). Paper for presentation at the ADB/AERC International Conference on Accelerating Africa's Development Five years into the Twenty-First Century, Tunis, Tunisia.

[33]. Raghavan, C. (2000). Development: FDI useful only when host control, direct, and regulate. South North Development Monitor(4621).

[34]. Tandon, Y. (2002). The role of FDI in Africa's Human Development. Harare, Zimbabwe.

[35]. Donou-Adonsou, F., \& Lim, S. (2018). On the importance of Chinese investment in Africa. Review of development finance, 8(1), 63 73. 
[36]. Meyersson, E., i Miquel, G. P., \& Qian, N. (2008). The rise of China and the natural resource curse in Africa. London School of Economics and Political Science, Economic Organisation and Public Policy Programme, http://personal. lse. ac. uk/padro/meyersonpadroqian_20080407_all.pdf.

[37]. Liu, A., \& Tang, B. (2018). US and China aid to Africa: Impact on the donor-recipient trade relations. China Economic Review, 48, 4665

[38]. Baliamoune - Lutz, M. (2011). Growth by destination (where you export matters): Trade with China and growth in African countries. African Development Review, 23(2), 202-218.

[39]. Habyarimana, J. B., \& Opoku, E. E. O. (2018). Technological progress, worker efficiency, and growth in Africa: Does China's economy matter?. China Economic Review, 52, 151-164.

[40]. Dong, Y., \& Fan, C. (2017). The effects of China's aid and trade on its ODI in African countries. Emerging Markets Review, 33, 1-18.

[41]. Tang, D., \& Gyasi, K. B. (2012). China-Africa foreign trade policies: the impact of China's foreign direct investment (FDI) flow on employment of Ghana. Energy Procedia, 16, 553-557.

[42]. Busse, M., Erdogan, C., \& Mühlen, H. (2016). China's impact on Africa-The role of trade, FDI and aid. Kyklos, 69(2), 228-262.

[43]. Doku, I., Akuma, J., \& Owusu-Afriyie, J. (2017). Effect of Chinese foreign direct investment on economic growth in Africa. Journal of Chinese Economic and Foreign Trade Studies, 10(2), 162-171.

[44]. Koomson-Abekah, I., \& Nwaba, E. C. (2018). Africa-China investment and growth link. Journal of Chinese Economic and Foreign Trade Studies, 11(2), 132-150.

[45]. Elu, J. U., \& Price, G. N. (2010). Does China transfer productivity enhancing technology to Sub - Saharan Africa? Evidence from manufacturing firms. African Development Review, 22, 587-598.

[46]. McCormick, D. (2008). China \& India as Africa's new donors: The impact of aid on development. Review of African political economy, 35(115), 73-92.

[47]. Maswana, J. C. (2009). A center-periphery perspective on Africa-China's emerging economic links. African and Asian studies, 8(12), 67-88.

[48]. Maswana, J. C. (2015). Colonial patterns in the growing Africa and China interaction: dependency and trade intensity perspectives. Journal of Pan African Studies, 8(7), 95-112.

[49]. Durden, Tyler (2012) The Beijing Conference": See How China Quietly Took Over Africa, retrieved from http://www.zerohedge.com/news/beijing-conference-see-howchinaquietly-took-over-africa, (18 September, 2012)

[50]. Sanusi, Lamido (2013) Africa must get real about Chinese ties, retrieved from http://www.ft.com/intl/cms/s/0/562692b0-898c-11e2ad3f00144feabdc0.html\#axzz2icnCpB10, (11 March, 2013)

[51]. Sala-i-Martin, X. (1994). Cross-sectional regressions and the empirics of economic growth. European Economic Review, 38(3-4), $739-747$.

[52]. Galor, Z. (1995). Dividing the results in a cooperative and the participation of members. Journal of the ICA, 4(3), 18-22.

[53]. Krugman, P. R. (1979). Increasing returns, monopolistic competition, and international trade. Journal of international Economics, 9(4), 469-479.

[54]. Helpman, E. (1999). The structure of foreign trade. Journal of Economic Perspectives, 13(2), 121-144.

[55]. Scheve, K. F., \& Slaughter, M. J. (2001). What determines individual trade-policy preferences?. Journal of International Economics, 54(2), 267-292

[56]. Fosu, A. K. (1990). Exports and economic growth: the African case. World Development, 18(6), 831-835.

[57]. Ulaşan, B. (2015). Trade openness and economic growth: panel evidence. Applied Economics Letters, 22(2), 163-167.

[58]. Trejos, S., \& Barboza, G. (2015). Dynamic estimation of the relationship between trade openness and output growth in Asia. Journal of Asian Economics, 36, 110-125.

[59]. Pedroni, P. (1999). Critical values for cointegration tests in heterogeneous panels with multiple regressors. Oxford Bulletin of Economics and statistics, 61(S1), 653-670.

[60]. Pedroni, P. (2004). Panel cointegration: asymptotic and finite sample properties of pooled time series tests with an application to the PPP hypothesis. Econometric theory, 20(3), 597-625.
[61]. Westerlund, J. (2005). New simple tests for pane cointegration. Econometric Reviews, 24(3), 297-316.

[62]. Pesaran, M. H., \& Smith, R. (1995). Estimating long-run relationships from dynamic heterogeneous panels. Journal of econometrics, 68(1), 79-113.

[63]. Eberhardt, M. (2012). Estimating panel time-series models with heterogeneous slopes. The Stata Journal, 12(1), 61-71.

[64]. Pesaran, M. H. (2006). Estimation and inference in large heterogeneous panels with a multifactor error structure. Econometrica, 74(4), 967-1012.

[65]. Pesaran, M. H. (2015). Time series and panel data econometrics. Oxford University Press.

[66]. Zahonogo, P. (2016). Trade and economic growth in developing countries: Evidence from sub-Saharan Africa. Journal of African Trade, 3(1-2), 41-56.

[67]. Giovannetti G., Sanfilippo M. (2016) Do Chinese Exports Crowd-out African Goods? An Econometric Analysis by Country and Sector. In: Henson S., Yap O.F. (eds) The Power of the Chinese Dragon. Palgrave Readers in Economics. Palgrave Macmillan, London

[68]. Ogundari, K., \& Awokuse, T. (2018). Human capita contribution to economic growth in Sub-Saharan Africa: Does health status matter more than education?. Economic Analysis and Policy, 58, 131-140.

[69]. Abdelbary, I., \& Benhin, J. (2019). Governance, capital and economic growth in the Arab Region. The Quarterly Review of Economics and Finance, 73, 184-191. 